\title{
SISTEM MONITORING KELEMBABAN GABAH PADI BERBASIS ARDUINO
}

\author{
I Ketut Wahyu Gunawan ${ }^{*}$, ,, Andi Nurkholis ${ }^{2)}$, Adi Sucipto ${ }^{3)}$, Afifudin ${ }^{4)}$ \\ ${ }^{1)}$ Program Studi Teknik Komputer, Fakultas Teknik dan Ilmu Komputer, Universitas Teknokrat Indonesia \\ Jl. ZA. Pagar Alam No.9 -11, Labuhan Ratu, Bandar Lampung, Indonesia 35132 \\ ${ }^{2)}$ Program Studi Informatika, Fakultas Teknik dan Ilmu Komputer, Universitas Teknokrat Indonesia \\ Jl. ZA. Pagar Alam No.9 -11, Labuhan Ratu, Bandar Lampung, Indonesia 35132 \\ ${ }^{3,4)}$ Program Studi Teknologi Informasi, Fakultas Teknik dan Ilmu Komputer, Universitas Teknokrat Indonesia \\ Jl. ZA. Pagar Alam No.9 -11, Labuhan Ratu, Bandar Lampung, Indonesia 35132
}

Email: ${ }^{1}$ ketutwahyugunawan@gmail.com

\begin{abstract}
The rice post-harvest problem that is still often encountered is the drying process which is still done manually, which only uses human senses as a measurement tool to find out the grain is dry or still wet. This has a weakness in use terms of human senses that are relative, so we need a system that effectively provides information on rice grain moisture. This study aims to create a system of monitoring rice grain moisture based on Arduino using DHT11 and Soil Moisture sensor. The system designed consists of several parts: power supply, control system, mechanical circuit, and program. The power supply is a power source for running an entire system consisting of voltage. The control system is an electronic circuit that functions as a data processor with a microcontroller as the control center. The next part is a mechanical circuit that functions to regulate the opening and release of dry and wet grain. The last part is a program that functions to regulate the microcontroller to run the system logic. Based on test results, the system can measure moisture and water content in rice grains, so as to minimize the damage to rice when milling is done.
\end{abstract}

Keywords: Arduino, grain, monitoring, moisture, rice post-harvest

\section{Abstrak}

Permasalahan dalam pascapanen padi yang masih sering ditemui adalah proses pengeringan yang masih dilakukan secara manual, dimana hanya menggunakan alat indra manusia sebagai alat ukur untuk mengetahui gabah tersebut kering atau masih basah. Hal tersebut memiliki kelemahan dalam hal penggunaan alat indra manusia yang bersifat relatif, sehingga dibutuhkan sebuah sistem yang efektif memberikan informasi kelembaban gabah padi. Penelitian ini bertujuan membuat sistem memonitoring kelembaban gabah padi berbasis Arduino menggunakan sensor DHT11 dan Soil Moisture. Sistem yang dirancang terdiri dari beberapa bagian yaitu: catu daya, sistem kontrol, rangkaian mekanika dan program. Catu daya merupakan sumber daya untuk menjalankan seluruh sistem yang terdiri dari tegangan. Sistem kontrol berupa rangkaian elektronik yang berfungsi sebagai pengolah data dengan mikrokontroler sebagai pusat kendali. Bagian selanjutnya adalah rangkaian mekanika yang berfungsi untuk mengatur buka tutup pengeluaran gabah kering dan gabah basah. Bagian terakhir adalah program yang berfungsi untuk mengatur mikrokontroler menjalankan logika sistem. Berdasarkan hasil pegujian, diperoleh bahwa sistem dapat megukur kelembaban dan kadar air pada gabah padi, sehingga mampu meminimalisir kerusakan beras ketika dilakukan penggilingan.

Kata Kunci: Arduino, gabah, kelembaban, monitoring, pascapanen padi

\section{Pendahuluan}

Pembangungan sektor pertanian terkhusus subsektor tanaman pangan memiliki peran yang sangat penting dan strategis sebagai salah satu penunjang kehidupan sebagian besar masyarakat Indonesia [1]. Hasil sensus pertanian tahun 2013 menunjukkan bahwa jumlah rumah tangga usaha tanaman pangan (padi dan palawija) mencapai 17.73 juta rumah tangga atau mencakup $67.83 \%$ dari total jumlah rumah tangga usaha tani, yang mencapai 26,14 juta rumah tangga pada tahun 2013 [2]. Berdasarkan data PDB tahun 2015, kontribusi subsektor tanaman pangan menunjukkan share terbesar kedua setelah tanaman perkebunan yaitu sebesar $3.41 \%$ dari total share Pertanian sebesar $10.28 \%$ terhadap PDB Indonesia [3]. Lebih lanjut, komoditas utama tanaman pangan di Indonesia yang mencapai 255.46 juta orang dengan laju petumbuhan $1.31 \%$ dan tingkat konsumsi beras rata-rata mencapai $124.89 \mathrm{~kg} / \mathrm{kapita} / \mathrm{tahun}$, sehingga dengan adanya pertambahan penduduk setiap tahun, maka peningkatan produksi beras saat ini menjadi prioritas dalam mengatasi kekurangan suplai.

Badan Pusat Statistik (BPS) mencatat pada tahun 2019, luas panen padi diperkirakan sebesar 10.68 juta hektare dengan produksi sebesar 54.60 juta ton Gabah 
Kering Giling (GKG) [4]. Jika dikonversikan menjadi beras, produksi beras pada 2019 mencapai sekitar 31,31 juta ton. Dibandingkan tahun 2018, produksi beras ini mengalami penurunan sebanyak 2.63 juta ton $(7.75 \%)$. Berkaitan dengan hal tersebut, Direktorat Jenderal Tanaman Pangan telah menetapkan strategi pencapaian produksi tanaman pangan yang salah satunya adalah peningkatan produktivitas dengan melakukan penurunan kehilangan hasil dan peningkatan rendemen beras yang termasuk dalam proses pascapanen [1].

Proses pascapanen padi yang dilakukan petani Indonesia khususnya di lampung terbilang masih sederhana yaitu proses pengeringan gabah masih di lakukan manusia secara manual. Pada proses pengeringan gabah menggunakan alat indra manusia sebagai alat ukur untuk mengetahui gabah tersebut kering atau masih basah. Hal tersebut memiliki banyak kelemahan karena tingkat akurasi alat indra manusia relatif atau tidak valid sehingga tidak ada nilai standar khusus untuk menentukan tanaman gabah itu sudah kering atau tidak kering. Permasalahan mengenai keefektifan dalam produksi pangan dapat diselesaikan salah satunya dengan memanfaatkan kemajuan teknologi [5].

Berdasarkan pemaparan sebelumnya, penelitian ini bertujuan mengembangkan sebuah sistem monitoring kelembaban berbasis mikrokontroler untuk meminimalisir kerusakan gabah padi yang disebabkan oleh pengeringan yang tidak sempurna. Sistem yang dikembangkan bekerja dengan memanfaatkan teknologi mikrokontroler Arduino yang dikombinasikan dengan sensor DHT11 dan sensor Soil Moisture untuk mengukur tingkat kelembaban gabah secara akurat. Setelah gabah diukur tingkat kelembabannya, maka nilai hasil akan ditampilkan dengan memanfaatkan Visual Studio sebagai monitoringnya dan Microsoft SQL Server 2012 sebagai basis data hasil pengukuran.

\section{Metode}

\section{A. Monitoring}

Monitoring merupakan proses rutin pengumpulan data dan pengukuran kemajuan atas objektif program memantau perubahan yang berfokus pada proses dan keluaran [6]. Monitoring menyediakan data dasar untuk menjawab permasalahan serta akan memberikan informasi tentang status dan kecenderungan bahwa pengukuran dan evaluasi yang diselesaikan berulang dari waktu ke waktu. Proses monitoring umumnya dilakukan untuk tujuan tertentu, untuk memeriksa terhadap proses suatu objek atau untuk mengevaluasi kondisi atau kemajuan menuju tujuan hasil manajemen atas efek tindakan dari beberapa jenis tindakan untuk mempertahankan manajemen yang sedang berjalan [7]. Pada penelitian ini, aktivitas monitoring bertujuan untuk mengetahui perubahan status dan keterangan kelembaban gabah padi pada periode waktu pascapanen hingga dilakukan proses penggilingan.

\section{B. Gabah}

Gabah merupakan buah dari tanaman padi yang berbentuk biji yang diselimuti oleh sekam. Bobot gabah pada kadar air 0\% berkisar antara 12 - $44 \mathrm{mg}$, sedangkan bobot sekam rata-rata sebesar $20 \%$ dari bobot gabah [8]. Kualitas fisik gabah sangat dipengaruhi oleh kadar air dan kemurnian gabah. Tingkat kemurnian gabah merupakan persentase berat gabah bernas terhadap berat keseluruhan campuran gabah. Tingkat kemurnian gabah akan semakin menurun dengan makin banyaknya benda asing atau gabah hampa di dalam campuran gabah [9].

Kadar air pada gabah yang temasuk dalam kategori gabah kering panen adalah tidak lebih dari 25\% [10], yang mana jika melebihi nilai tersebut maka gabah padi termasuk dalam kategori lembab. Kelembaban merupakan suatu tingkat keadaan lingkungan udara basah yang disebabkan oleh adanya uap air. Tingkat kelembaban pada penelitian ini menggunakan formulasi Persamaan 1 .

$$
\text { kelembaban }=\frac{\text { kelembaban mutlak }}{\text { jumlah uap air maksimum }} \times 100 \%
$$

C. Alat

Penelitian ini dilakukan menggunakan perangkat keras dan perangkat lunak sebagai berikut:

1. Microsoft Visual Studio 2017, digunakan sebagai sebagai editor dalam membuat sintaks pemrograman $\mathrm{C \#}$ yang digunakan dalam membuat interface/tampilan berupa aplikasi yang dapat menampilkan informasi kelembaban gabah berdasarkan data pada Microsoft SQL Server.

2. Microsoft SQL Server 2012, digunakan sebagai tempat penyimpanan data suhu dalam suatu periode waktu. Pada penerapannya, database ini akan merekam data berdasarkan hasil monitoring sensor DHT11 dan Soil Moisture, yang kemudian akan ditampilkan menjadi informasi kelembaban.

3. Sketch Up, digunakan untuk membuat dasain model 3D rangkaian mekanika yang dijadikan sebagai wadah dari kesatuan sistem.

4. Mikrokontroler Arduino IDE, digunakan untuk melakukan aktivitas pemrograman dalam mengkonfigurasi mikrokontroler Arduino agar dapat dikombinasikan dengan beberapa perangkat keras lainnya [11].

5. Mikrokontroler Arduino, suatu chip berupa IC (Integrated Circuit) yang dapat menerima sinyal input, mengolahnya dan memberikan sinyal output sesuai dengan program yang diisikan ke dalamnya. Sinyal input mikrokontroler berasal dari sensor yang merupakan informasi dari lingkungan sedangkan sinyal output ditujukan kepada aktuator yang dapat memberikan efek ke lingkungan. Jadi secara sederhana mikrokontroler dapat diibaratkan sebagai otak dari suatu perangkat atau produk yang mampu berinteraksi dengan lingkungan. Arduino juga dikenal sebagai proyek open source yang memungkinkan siapa saja, termasuk yang tidak berlatar belakang pendidikan elektronika dapat membuat prototipe sistem elektronika dengan mudah 


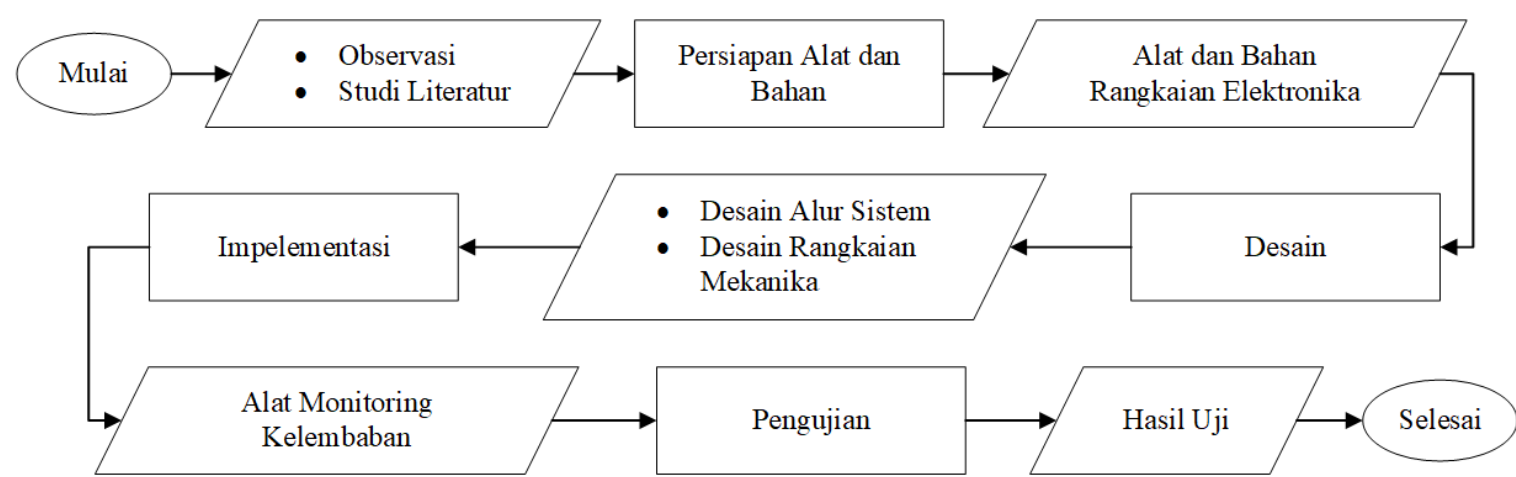

Gambar 3. Diagram alir penelitian

dan bahkan tanpa melibatkan solder [12]. Pada penelitian ini, mikrokontroler Arduino digunakan sebagai sistem pusat dalam menyatukan perangkatperangkat keras lainnya.

6. Sensor DHT11, sensor dengan kalibrasi sinyal digital yang mampu memberikan informasi suhu dan kelembaban. Sensor ini tergolong komponen yang memiliki tingkat stabilitas yang baik, serta ditambah dengan kemampuan mikrokontroler 8 bit seperti Arduino. Koefisien kalibrasi DHT11 disimpan dalam OTP program memori, sehingga ketika internal sensor mendeteksi sesuatu, maka modul ini membaca koefisien sensor. Sensor DHT11 dalam penelitian ini digunakan dalam memonitoring perubahan tingkat kelembaban gabah padi.

7. Sensor Soil Moisture, digunakan sebagai alat pemantau kelembaban dalam tanah. Sensor ini membantu mendeteksi langsung nilai kelembaban tanah yang menunjukkan banyaknya kadar air di dalam tanah dengan memadukannya dengan mikrokontroller.

8. Relay, digunakan sebagai media perantara untuk menggerakkan Kontak Saklar sehingga dengan arus listrik yang kecil (low power) dapat menghantarkan listrik yang bertegangan lebih tinggi.

9. Motor Servo, suatu perangkat putar (actuator) yang dirangkai dengan kontrol umpan balik atau loop tertutup sehingga perangkat tersebut dapat diatur untuk memastikan dan menentukan posisi dari sudut poros output motor. Sistem kontrol umpan balik (loop) di motor servo memiliki kegunaan yakni untuk mengontrol pergerakan dan posisi akhir poros. Lebih tepatnya, posisi poros keluaran (output) akan di deteksi dengan tujuan untuk mengetahui apakah posisi poros sudah sesuai yang kita inginkan atau malah belum. Jika posisi poros belum sesuai, maka sistem kontrol akan memberikan sinyal agar posisi poros sesuai dengan apa yang diinginkan.

10. Light Emiting Diode (LED), komponen yang dapat memancarkan cahaya. LED merupakan komponen elektronik dari bahan semikonduktor yang dapat memancarkan cahaya monokromatik jika diberi tegangan maju [12]. LED merupakan salah satu jenis dioda, sehingga hanya akan mengalirkan arus listrik satu arah saja. LED akan memancarkan cahaya apabila diberikan tegangan listrik dengan konfigurasi forward bias. Berbeda dengan dioda pada umumnya, kemampuan mengalirkan arus pada LED cukup rendah yaitu maksimal $20 \mathrm{~mA}$. Apabila LED dialiri arus lebih besar dari $20 \mathrm{~mA}$ maka LED akan rusak, sehingga pada rangkaian LED dipasang sebuah resistor sebagai pembatas arus.

11. Resistor, komponen listrik yang membatasi atau mengatur aliran arus listrik di sebuah sirkuit elektronik. Kemampuan resistor untuk membatasi atau mengatur aliran arus listrik disebut resistensi dan diukur dalam satuan Ohm. Resistor diciptakan menggunakan karbon pasir dicampur dengan tanah liat dan terdapat juga resistor yang diciptakan menggunakan kawat nichrome. Komponen ini disebut resistor wirewood dan mampu menangani arus yang lebih tinggi daripada bahan karbon. Pada resistor mempunyai nilai yang berbeda-beda. Nilai tersebut dilihat dari banyaknya warna yang terdapat di resistor.

12. Kerangka Mekanika, wadah kesatuan dari perangkat-perangkat yang digunakan dalam menyusun sistem monitoring menjadi alat terapan. Berikut rangkaian mekanika yang digambarkan oleh blok diagram sebagai acuan dalam proses penempatan seluruh komponen yang saling terhubung ditunjukkan pada Gambar 2.

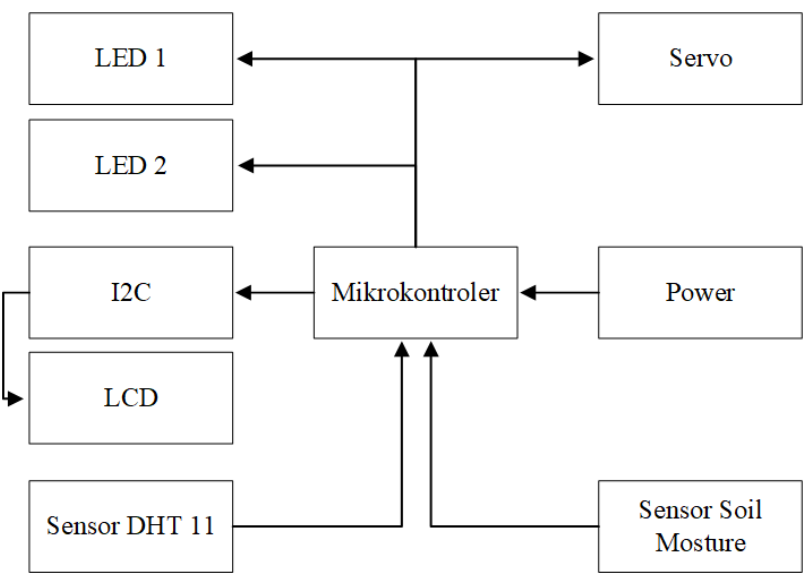

Gambar 2. Blok diagram perancangan sistem

Keterangan dari blok diagram pada Gambar 2 adalah:

- Power sebagai input tegangan ke mikrokontroler menggunakan arus DC $5 \mathrm{~V}$.

- Arduino MEGA sebagai mikrokontroler untuk 
mengendalikan servo yang mendapat tegangan dari power.

- Servo MG995 sebagai actuator untuk membuka dan menutup padi basah dan kering.

- I2C sebagai serial komunikasi megirim dan menerima perintah dari mikrokontroler ke LCD.

- LCD sebagai output dari perintah mikrokontroler

- Sensor DHT11 sebagai alat ukur kelembaban dan suhu pada padi.

- Sensor soil moisture sebagai alat ukur kadar air dalam padi.

- LED 1 sebagai indikator yang menandakan bahwa padi dinyatakan kering.

- LED 2 sebagai indikator yang menandakan bahwa padi dinyatakan basah.

D. Tahapan Penelitian

Penelitian yang dilakukan mencakup beberapa tahapan yaitu, studi literatur dan observasi, persiapan alat dan bahan, desain, implementasi, pengujian. Diagram alir dari tahapan penelitian dapat dilihat pada Gambar 3.

Pada Gambar 3 dapat dilihat ada lima tahapan penelitian yang dilakukan, berikut penjelasannya:

\section{Pengumpulan Data}

Tahap ini dilakukan untuk mengumpulkan data-data yang dibutuhkan dalam penelitian. Dalam penelitian ini pengumpulan data dilakukan dengan metode studi literatur dan observasi. Metode ini dilakukan dengan cara membaca dan mempelajari buku-buku yang berhubungan dengan Arduino dan sensor, sistem kontrol. Demi tercapainya kegunaan pada sistem yang dikembangkan, pengumpulan data juga dilakukan dengan melakukan observasi langsung di lahan tani untuk memperoleh spesifikasi alat yang dibutuhkan secara tepat.

\section{Persiapan Alat dan Bahan}

Setelah sebelumnya dilakukan studi literatur dan observasi hingga didapatkan alat dan bahan yang diperlukan dalam perancangan sistem ini. Pemilihan jenis komponen elektronika dalam perancangan dan pembuatan suatu perangkat elektronika harus dilakukan karena berdampak langsung pada tingkat efisiensi dan efektifitas perangkat yang akan dibuat. Beberapa hal yang perlu diperhatikan diantaranya memilih komponen pendukung yang telah ditentukan oleh cara kerja rangkaian baik secara keseluruhan ataupun secara perblok rangkaian, memperhitungkan karakteristik suatu komponen elektronika yang akan digunakan agar mecapai hasil yang optimal, dan memilih komponen yang akan dibutuhkan secara efektif dan efisien.

\section{Desain}

Pada tahap ini, desain terbagi menjadi dua bagian, yaitu desain alur sistem dan desain rangkaian mekanika.

- Desain alur sistem dilakukan dengan membuat flowchart yang menjelaskan secara rinci langkahlangkah dari proses sistem yang dikembangkan. Tahap ini dilakukan sebelum membuat program dengan tujuan mempermudah program yang akan dibuat pada tahap implementasi, dengan diagram kerja, alat akan mudah dipahami bagaimana cara kerja dari program alat (device) yang dirancang. Berikut diagram alir rancangan sistem yang ditunjukkan pada Gambar 4.

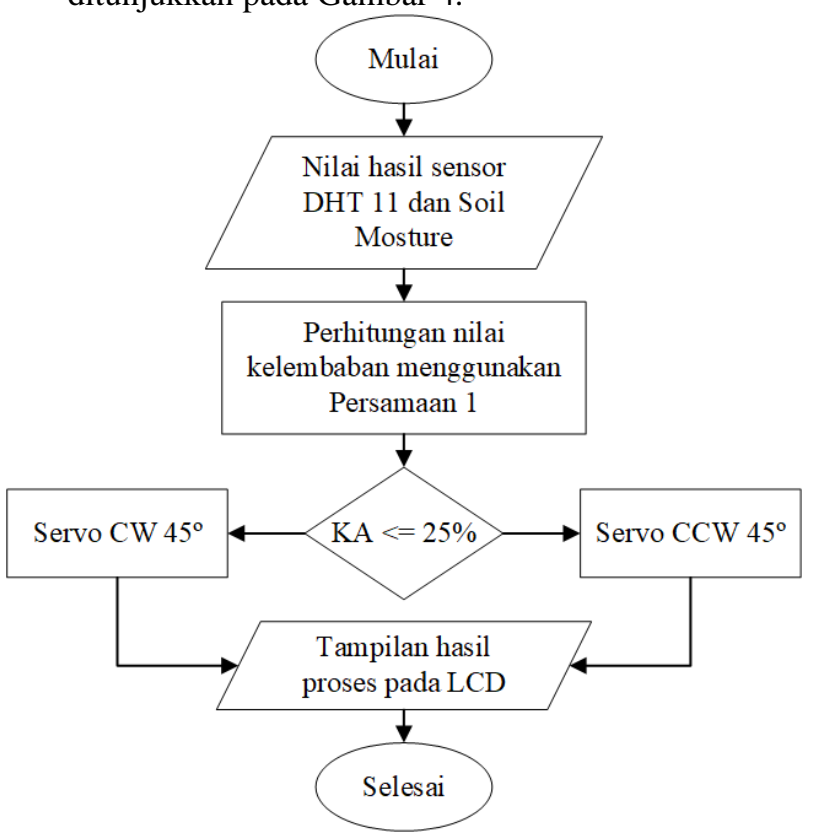

Gambar 4. Diagram alir rancangan sistem

- Desain rangkaian mekanika merupakan proses perancangan bagian-bagian mekanik menjadi satu kesatuan yang saling berhubungan sehingga membentuk alat yang nantinya dapat digunakan. Proses pengerjaan harus mendukung perangkat elektronik dengan mengutamakan letak penempatannya agar dapat berjalan sesuai dengan fungsinya. Desain rangkaian mekanika berupa alat monitoring kelembaban gabah dibuat berdasarkan kebutuhan petani khususnya petani padi. Tahap ini dilakukan dengan menggunakan bantuan software Sketch Up. Berikut rancangan desain rangkaian mekanika yang dapat dilihat pada Gambar 5.

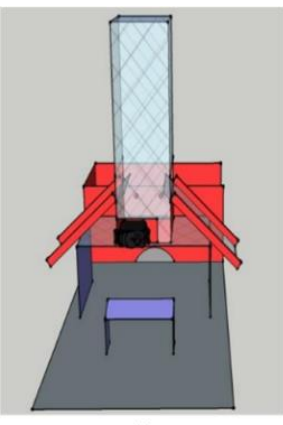

(a)

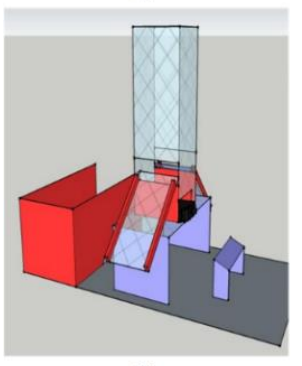

(c)

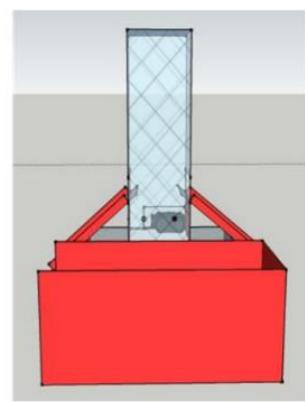

(b)

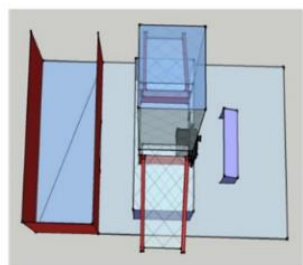

(d)
Gambar 5. Rangkaian mekanika, bagian (a) depan, (b) belakang, (c) samping, dan (d) atas 


\section{Implementasi}

Pada tahap ini dilakukan penerapan terhadap desain yang telah dibuat untuk menjadi sebuah kesatuan sistem. Tahap implementasi terbagi menjadi dua bagian, yaitu pemrograman dan perakitan rangkaian mekanika.

- Pemrograman dilakukan menggunakan bahasa pemrograman bahasa Arduino yang merupakan turunan dari bahasa pemrograman bahasa $\mathrm{C} / \mathrm{C}++$ dengan menggunakan tool Arduino IDE. Arduino menggunakan konsep pemrograman berorientasi objek dimana program dipaket dalam sebuah library atau class program. Pada pemrograman Arduino memberikan fasilitas yang dapat memudahkan dengan banyaknya library untuk memproses suatu sistem.

- Perakitan rangkaian mekanika dilakukan untuk menyatukan komponen mekanika sesuai dengan desain rangkaian yang sudah dibuat agar nantinya alat tersebut dapat bekerja dengan maksimal sesuai dengan apa yang diharapkan. Tahap perakitan terbagi menjadi dua tahap, yaitu perakitan mekanik alat monitoring kelembaban padi dan perakitan koneksi modul elektronika dengan mengacu pada desain yang telah dibuat sebelumnya. Perakitan dilakukan setelah kerangka alat monitoring selesai dibuat, yang kemudian semua modul beserta sensor ditempatkan pada posisi dalam kerangka pengaman pintu. Posisi sensor diletakkan dengan sangat presisi dikarenakan mempengaruhi saat alat monitoring melakukan pembacaan terhadap inputan kelembaban dan ph pada padi. Gambar 6 Memperlihatkan koneksi modul-modul elektronik sebelum terintegrasi kedalam rangkaian mekanika alat monitoring.

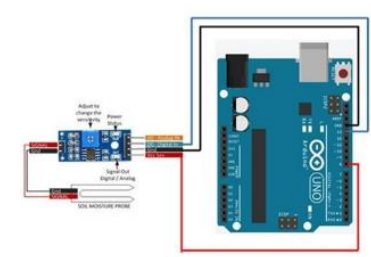

(a)

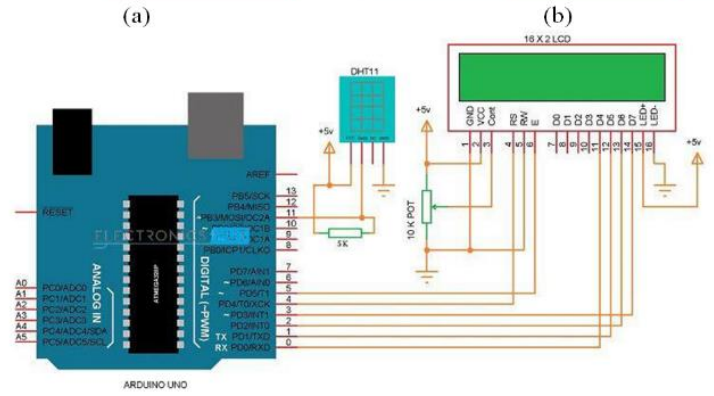

(c)

Gambar 6. Koneksi modul (a) Arduino dan sensor soil moisture, (b) Arduino dan motor servo, dan (c) Arduino, LCD 16x2 dan sensor DHT11

\section{Pengujian}

Pengujian dilakukan pada petani lampung dengan cara perangkat yang dibuat dipasang pada hasil panen padi yang bertujuan untuk mengetahui tingkat air dan kelembaban gabah. Pengujian dilakukan secara sistematis dan terkontrol dengan langkah-langkah penelitian yang sesuai dengan metode penelitian yang diterapkan.

\section{Hasil dan Pembahasan}

Sistem monitoring kelembaban padi menggunakan sensor kelembaban berbasis Arduino yang terdiri dari 1 buah motor servo, soil moisture, sensor DHT, LCD (Liquid Crystal Display), dan 1 buah Mikrokontroler Arduino UNO dengan masing-masing fungsi, yaitu a) Sensor DHT 11 dan soil moisture berfungsi sebagai pegukur suhu dan kelembaban pada padi; b) Motor servo berfungsi sebagai pembuka tutup wadah penampung padi; c) LCD (Liquid Crystal Display) berfungsi sebagai penampil status tingkat kelembaban padi; dan d) Mikrokontroler Arduino sebagai pusat dan pemroses keseluruhan komponen sistem. Dalam pembuatan sistem ini digunakan perangkat lunak Arduino IDE pada sistem operasi Windows 10 Pro 64 bit. Sistem monitoring kelembaban dapat dilihat pada Gambar 7.

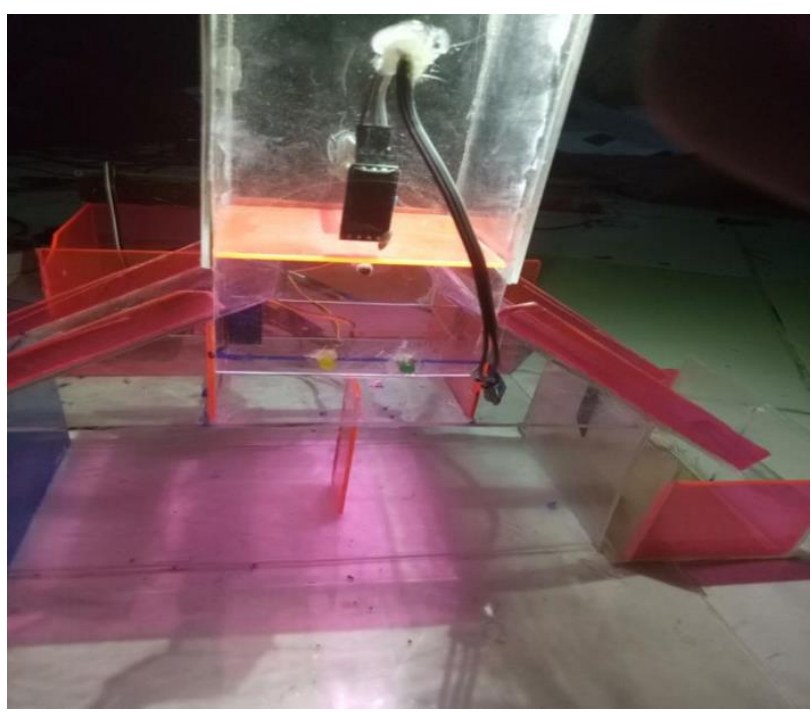

Gambar 7. Sistem monitoring kelembaban padi berbasis Arduino

Tahapan yang selanjutnya dilakukan adalah melakukan uji terhadap sistem yang telah dikembangkan. Tujuan dari pengujian ini adalah untuk membuktikan apakah sistem yang dibuat memenuhi spesifikasi yang telah direncanakan. Hasil pengujian akan dimanfaatkan untuk menyempurnakan kinerja sistem dan sekaligus digunakan dalam pengembangan lebih lanjut. Pengujian sistem ini terdiri dari beberapa tahapan, dimulai dari pengujian terhadap komponen sistem hingga pengujian sistem secara keseluruhan. Dari hasil pengujian maka dapat dianalisa kinerja dari komponen-komponen sistem yang saling berinteraksi. Pengujian terhadap keseluruhan sistem berguna untuk mengetahui bagaimana kinerja dan tingkat keberhasilan dari sistem tersebut. Tahapan pengujian akan dilakukan dengan urutan sebagai berikut, a) Pengujian fungsi komponen sistem; b) Pengujian kinerja sistem. 


\section{A) Pengujian Fungsi Komponen Sistem}

Pengujian yang dilakukan pada tahap ini meliputi pengujian catu daya, pengujian Arduino UNO, dan pengujian motor servo. Berikut penjelasannya:

\section{Pengujian Catu Daya}

Pada tahap pengujian ini yang dilakukan adalah mengukur tegangan dari catu daya yang masuk ke pin GND dan VIN dari adaptor. Pengujian ini bertujuan untuk memastikan apakah daya yang dihasilkan oleh adaptor dapat digunakan secara utuh oleh Mikrokontroler beserta motor servo dan lampu LED indicator yang membutuhkan daya antara 4.2 Volt -5 Volt DC. Alat yang digunakan dalam pengujian ini yaitu AVOmeter yang dihubungkan dengan pin GND dan VIN. Berikut hasil Ppengujian tegangan catu daya yang ditunjukkan oleh Gambar 8.

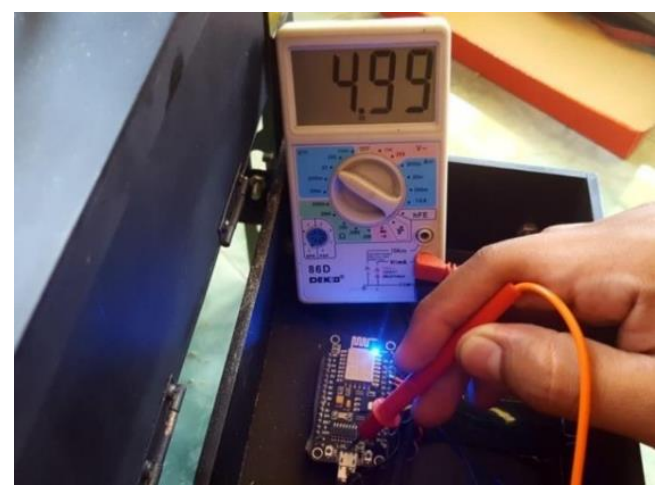

Gambar 8. Hasil pengujian catu daya

\section{Pengujian Arduino UNO}

Pada tahap ini pengujian yang dilakukan bertujuan untuk menguji apakah Mikrokontroler Arduino UNO dapat menerima kode program dengan baik atau tidak dengan cara mengunggah kode program ke Mikrokontroler menggunakan aplikasi Arduino IDE dan memastikan bahwa proses unggah selesai $100 \%$. Berikut adalah hasil pengujian Arduino UNO ditunjukkan pada Gambar 9.

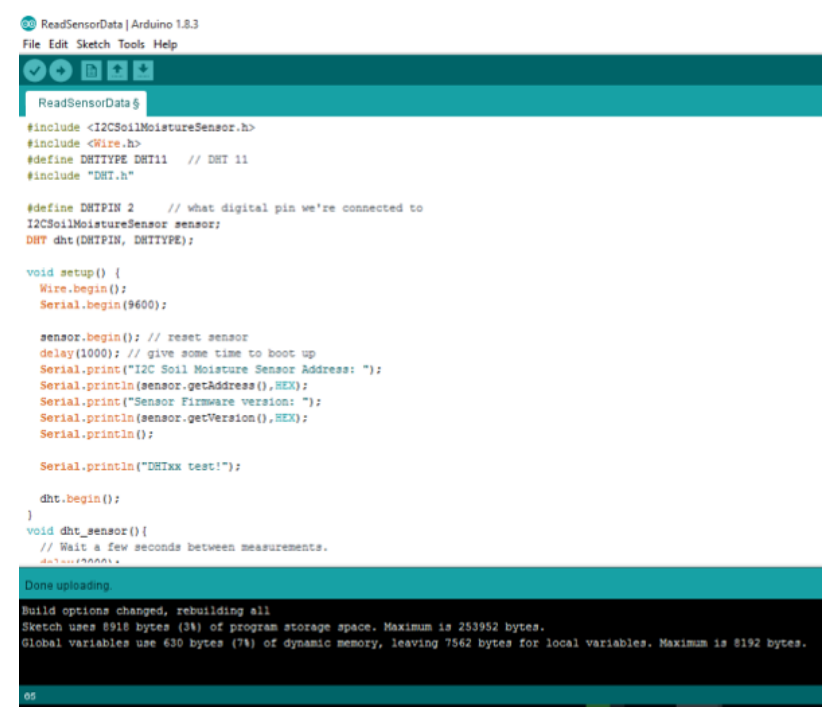

Gambar 9. Pengujian Arduino UNO

\section{Pengujian Motor Servo}

Pengujian yang dilakukan pada motor servo bertujuan untuk mengukur derajat rotasi yang diperlukan untuk membuka dan menutup katup servo. Pengujian pada motor servo dilakukan dengan memberikan nilai derajat rotasi pada kode program lalu program tersebut diunggah ke Mikrokontroler. Berikut Gambar 10 penempatan motor servo pada alat.

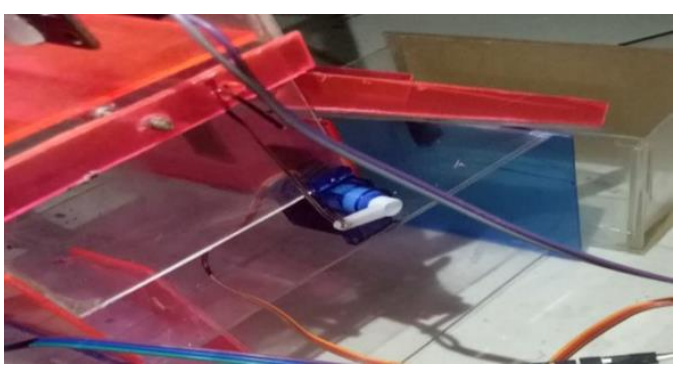

Gambar 10. Penempatan motor servo pada alat

Pada Gambar 9 menunjukkan posisi servo tertutup dengan derajat rotasi $0^{\circ}$ sehingga menopang agar gabah padi tidak keluar dari wadah untuk menentukan nilai apakah gabah padi kering atau basah. Berikut keterangan nilai derajat rotasi servo ditunjukkan pada Tabel 1 .

Tabel 1. Nilai derajat rotasi servo

\begin{tabular}{ccc}
\hline Perangkat & Derajat Rotasi $\left({ }^{\circ}\right)$ & Status Katup \\
\hline \multirow{3}{*}{ Servo } & 0 & Tertutup \\
& $45, \mathrm{CW}$ & Terbuka \\
& $45, \mathrm{CCW}$ & Terbuka \\
\hline
\end{tabular}

Tabel 2. Pengujian jumlah gabah

\begin{tabular}{ccc}
\hline Percobaan & Jumlah Gabah & Keterangan \\
\hline 1 & $225 \mathrm{~g}$ & Sukses \\
2 & $225 \mathrm{~g}$ & Sukses \\
3 & $220 \mathrm{~g}$ & Sukses \\
4 & $205 \mathrm{~g}$ & Sukses \\
5 & $1 \mathrm{~kg}$ & Tidak sukses \\
6 & $1.5 \mathrm{~kg}$ & Tidak sukses \\
\hline
\end{tabular}

Pada Tabel 2 menunjukkan bahwa percobaan 1 sampai percobaan 4 sukses karena yang terisi di penampung Gabah adalah kisaran 200 g sampai 225 g. Untuk percobaan 5 dan percobaan 6 tidak sukses karena tidak sesuai dengan ketentuan diantara wadah penampung gabah $1 \mathrm{~kg}$ sampai $1.5 \mathrm{~kg}$ saat pengisian gabah ke wadah. Hal tersebut menyebabkan wadah megalami kerusakan dan tidak dapat bergerak saat sistem di jalankan.

B) Pengujian Kinerja Sistem

Pada tahap ini pengujian dilakukan untuk mengetahui kinerja dari alat dimulai dari durasi yang 
diperlukan untuk mencapai gabah turun pada wadah penampung dan kemudian halaman utama yang terdapat tombol alat, untuk me-restart pada servo dan program alat tempat waktu. Tahap pertama melakukan uji coba saat alat di sambungkan ke listrik. Berikut hasil durasi pada alat ditunjukkan pada Tabel 3 .

Tabel 3. Hasil pengujian durasi pada alat

\begin{tabular}{cc}
\hline Percobaan & Durasi (detik) \\
\hline 1 & 5.33 \\
2 & 4.20 \\
3 & 5.32 \\
4 & 4.92 \\
5 & 4.60 \\
Rata-rata & 4.88 \\
\hline
\end{tabular}

Kemudian dilakukan pengujian terhadap alat dan sensor untuk mencapai. sensor menghitung kadar air dan kelembaban pada gabah.

Tabel 4. Hasil pengujian durasi menghitung kelembaban gabah

\begin{tabular}{cc}
\hline Percobaan & Durasi (detik) \\
\hline 1 & 2.97 \\
2 & 2.17 \\
3 & 2.89 \\
4 & 2.64 \\
5 & 2.51 \\
Rata-rata & 2.63 \\
\hline
\end{tabular}

Rata-rata waktu yang didapat untuk mencapai hasil yang di hitung oleh sensor adalah 4.88 detik. Sedangkan untuk mencapai wadah gabah adalah 2.63 detik.

\section{Kesimpulan dan Saran}

Penelitian ini menghasilkan sistem monitoring kelembaban gabah padi yang berdasarkan pengujian mampu mengukur kelembaban dan kadar air pada gabah padi, sehingga dapat meminimalisir kerusakan beras saat digiling. Sistem monitoring diterapkan dengan memanfaatkan teknologi mikrokontroler yang dikombinasikan dengan beberapa komponen, yaitu sensor DHT11, sensor soil moisture, motor servo, fan DC, LED, dan relay.

Penelitian selanjutnya diharapkan dapat mengembangkan beberapa hal, yaitu: 1) Penambahan komponen berupa dua servo atau lebih untuk mendukung penggerak pada tahap gabah padi kering dan gabah padi basah supaya pengontrolan dapat lebih luas. 2) Penambahan wadah penampung gabar agar tidak mengganggu kerja alat pada bagian penggerak suatu perputaran motor servo sehingga sensor mampu berkerja secara baik dan optimal. 3) Penambahan suatu batasan di wadah penampung, agar gabah padi yang diukur dapat turun tepat pada wadah yg telah disediakan.

\section{Daftar Pustaka}

[1] Pusat Data dan Sistem Informasi Pertanian (PUSDATIN), "Outlook Komoditas Pertanian Sub Sektor Tanaman Pangan, Padi," PUSDATINKementerian Pertanian, issn:1907-1507, 2016.

[2] Subdirektorat Statistik Tanaman Pangan, "Sensus Pertanian 2013, Angka Nasional Hasil Survei Rumah Tangga Usaha Tanaman Padi, 2014," Badan Pusat Statistik, isbn: 978-979-064-815-9, 2015

[3] Pusat Data dan Sistem Informasi Pertanian (PUSDATIN), "Outlook Komoditas Pertanian Sub Sektor Tanaman Pangan, Padi," PUSDATINKementerian Pertanian, issn:1907-1507, 2015.

[4] Direktur Statistik Tanaman Pangan Hortikultura dan Perkebunan, "Luas Panen dan Produksi Padi di Indonesia 2019," Badan Pusat Statistik, 2020.

[5] A. Nurkholis and I. S. Sitanggang, "A Spatial Analysis Of Soybean Land Suitability Using Spatial Decision Tree Algorithm," In Proc. SPIE 11372, Sixth International Symposium on LAPAN-IPB Satellite, p. 113720I, 2019.

[6] P. Yahwe, Caesar, Isnawaty, dan L.M. Fid Aksara, "Rancang Bangun Prototype System Monitoring Kelembaban Tanah Melalui SMS Berdasarkan Hasil PenyiramanTanaman", semanTIK, Vol. 2, No. 1, pp. 97-110, 2016.

[7] D.E. Kurniawan, M. Iqbal, J. Friadi, R.I. Borman dan R. Rinaldi, "Smart Monitoring Temperature and Humidity of the Room Server Using Raspberry Pi and Whatsapp Notifications," In Journal of Physics: Conference Series (Vol. 1351, No. 1, p. 012006) IOP Publishing, 2019.

[8] S. Yoshida, "Fundamental of Rice Crop Science," The International Rice Research and Institute, Philiphine, 1981.

[9] Bulog, "Sekilas Raskin (Beras untuk Rakyat Miskin)," Bulog, 2008.

[10] S. Samsugi dan D.E. Silaban, "Purwarupa Controlling Box Pembersih Wortel Dengan Mikrokontroler," Prosiding Nasional Rekayasa Teknologi Industri dan Informasi XIII (ReTII), pp. $1-7,2018$

[11] A. Kadir, "Panduan Praktis Mempelajari Aplikasi Mikrokontroler dan Pemrogramannya Menggunakan Arduino," Yogyakarta: Penerbit ANDI, 2013.

[12] D. Arifianto dan Winarno, "Bikin Robot Itu Gampang," Surabaya: Penerbit PT Kawan Pustaka, 2011. 